\title{
Contributions of Ordinary Citizens Towards Development of a Society: The Case of Bangladesh
}

\author{
Ishtiaq Hossain ${ }^{\#, *}$
}

\author{
Department of Political Science, International Islamic University Malaysia, Kuala Lumpur, Malaysia
}

\begin{abstract}
This paper highlights the contributions of ordinary citizens to the development of a developing country Bangladesh. The article discusses the contributions made by two ordinary citizens of Bangladesh, Begum Rokeya Sakhawat Hossain and Khondker Azizur Rahman Salim, toward building the society. It is argued in this paper that the participation of ordinary citizens in the development of a society is important. While the elites of a society may lay down the strategy, and sometimes the policies for developing such a society, ordinary citizens on their own can, in fact, play an important role in those regards. This paper highlights the strategies adopted by those two common citizens. It also chronicles their sufferings, sacrifices and achievements. The paper concludes that while the contributions made by Begum Rokeya Sakhawat Hossain is celebrated, those of Khondker Azizur Rahman Salim remains unrecognised by the Bangladesh society. The paper adopts qualitative research method. Information about Begum Rokeya Sakhawat Hossain have been collected from works done by her and by others on her. Khondker Azizur Rahman was interviewed both in Dhaka, Bangladesh and Maryland, the United States, where he currently lives.
\end{abstract}

Keywords: Ordinary Citizens, Contributions, Development, Begum Rokeya Sakhawat Hossain, Khondker Azizur Rahman Salim, Bangladesh.

\section{INTRODUCTION}

Throughout history, contributions to society made by leaders like Mahatma Gandhi, Nelson Mandela, and Reverend Martin Luther King Jr. have been celebrated. But the role played by ordinary citizens in building their respective societies are seldom highlighted. This paper is aimed at highlighting the works of ordinary citizensin a developing society. The paper chooses Bangladesh as a case study, and discusses the contributions made by two ordinary citizens of the country, Begum Rokeya Sakhawat Hossain and Khondker Azizur Rahman Salim, toward building the society. While Begum Rokeya worked for the uplifting of Muslim female education, Khondker Azizur Rahman contributed immensely to the adoption of a new Drug Policy for the country. This paper highlights their strategies, sufferings, sacrifices and achievements.

In the first section of the paper, a brief rationale is provided for choosing Bangladesh as a case study. In the second section, a background to the country's socio-economic and political conditions are provided so that the readers are aware of the political and

\footnotetext{
*Address correspondence to this author at the Department of Political Science, International Islamic University Malaysia, Kuala Lumpur, Malaysia;

Tel: +60-3-6196 6053; Fax: +60-3-4278 1110; E-mail: ihossain@iium.edu.my, ishtiaq.hossain@gmail.com

"Hisrecent publications are the following: The Russian Military Intervention in Syria: Background, Causes and Consequences (Beirut: al-Zaytouna Centre for Studies and Consultations, November, 2015); (with Isiaka Abiodun Adams)"Human Security in a Globalised World: Concepts, and Issues for the Muslim World," in Samiul Hasan (ed.), Philanthropy and Human Security in the Muslim World: Concepts, Characters, and Challenges(New York: Springer, 2015); and "Arab Spring," in Emad El-Din Shahin (ed.). The Oxford Encyclopedia of Islam and Politics. New York: Oxford University Press, 2014, pp. 98-102.
}

economic issues be devilling the Bangladeshi society. The paper concludes that while the contributions made by Begum Rokeya Sakhawat Hossain is celebrated, however, those of Khondker Azizur Rahman Salim remains unrecognised by the society. The paper adopts qualitative research method. Information about Begum Rokeya Sakhawat Hossain have been collected from works done by her and by others on her. In particular, Mohammad A. Quayum's The Essential Rokeya: Selected Works of Rokeya Sakhawat Hossain (1880-1932) has been useful for biographical information about her. This book also translated the major works of Begum Rokeya. Interviews were conducted with Khondker Azizur Rahman Salim both in Dhaka, Bangladesh and Maryland, in the United States, where he currently lives.

\section{THE RATIONALE}

As a developing state Bangladesh's capacity to provide essential services to its citizens and carrying out development works is indeed limited. Therefore, as Rahman points out, NGOs are viewed by donors and policy-makers as a grassroots-oriented alternative to corrupt or inefficient government agencies and they have come to play an increasingly central role in shaping and implementing development policies in Bangladesh (Rahman, 2006: 451). It is therefore not surprising that innumerable works have been published highlighting thepositive contributions made by various NGOs like the Grameen Bank, Bangladesh Rural Advancement Committee (BRAC), Proshika etc. and their founders like the Nobel Peace prize winner 
Professor Yunus of the Grameen Bank and of BRAC to the development of Bangladesh (Ahmed 2008, Fernando 1997, and 1999, Holcombe 1995, Gauri and Galef 2005, Hossain 1998,Morduch 1999, Wahid and Hsu 2000). But very little attention have been paid to the contributions made by ordinary Bangladesh citizens to the cause of building their society and thereby contributing towards building peace in the country. The paper focuses on two ordinary citizens of Bangladesh, Begum Rokeya Sakhawat Hossain and Khondker Azizur Rahman Salim. This paper highlights their strategies, sufferings, sacrifices and achievements. Begum Rokeya was a house-wife who lived during the late nineteenth and early twentieth century. She contributed immensely to the education of Muslim women at a time when their education was confined only to religious knowledge. In her novel Sultana's Dream, Begum Rokeya thought of a society where women were not only equal to men but actually dominate the society. In this sense she was ahead of contemporary feminists who are still clamouring for equality of women. Azizur Rahman, on the other hand, is a product of the twentieth century. Owner of a string of business interests that included a pharmaceutical industry, and a trading house, he took great interest in the quality of medicines. He was an enthusiastic supporter of making changes to the country's antiquate policy regulating the pharmaceutical industries during the 1980s. Knowing full well that his own business interest would be affected by any changes in government's policy on pharmaceutical industry, Rahman played a humble but important role in the formulation of Bangladesh's policy on pharmaceuticals in 1982. Azizur Rahman is disturbed by poverty of ordinary people especially that of children. He along with his physician friend set up a NGO to bring free medicines and education to rural children in the south of the country.

\section{THE BACKGROUND}

Zoellick (2009) defines a fragile state having the following main characteristics: ineffective government, poverty and conflict. In this sense, Bangladesh, a country of more than 170 million people, can be considered a fragile state. Since the creation of the country in 1971 successive governments in Bangladesh have been unable to carry out some of the core functions of the State like providing enough pure water, electricity, sewerage, employment, health care, and security to the majority of its population. In spite of the positive impact of micro-finance on the alleviation of poverty in Bangladesh, half of the country's population still lives in poverty. Conflict in the country may not be as endemic as that in Afghanistan, Iraq, Pakistan, the Democratic Republic of Congo, Somalia but Bangladesh suffers from prevalent political and social conflicts. In addition to the characteristics of a fragile state laid down by Zoellick, Bangladesh also suffers from a 'sovereignty gap' (Ghani and Lockhart, 2008) an ever-widening gap between the state's capacity to govern by law and its capacity to provide for the needs of the people in practice. Worse still, Bangladesh also runs a higher risk of conflict because of low and stagnant incomes, high unemployment and ineffective governance. In short, Bangladesh is in the midst of internal crises which could potentially undermine the long-term national stability (Barthwell-Datta, 2009, Rahman, 2006).

Bangladesh is infamous for its poverty. But what is not very well-known is that this was not always the case. The land now known as Bangladesh wasonce well-known as the granary of the Indian subcontinent. The area was also famous for the production of an exquisite fine cloth called Muslin that had become very well known in European royal courts. The country endured a long period of colonial rule lasting for nearly 190 years and had been subject to ruthless exploitation. The British colonised the country from June 24, 1757, to August 14, 1947. When the British decided to leave India in 1947, the people of East Bengal, majority of whom were Muslims decided to join Pakistan. Separated by eleven hundred miles of Indian Territory, East Pakistan was ruled from Islamabad. Although Islam bound the two provinces of Pakistan East and West Pakistan - together, fault lines soon appeared threatening the unity of Pakistan. One major salvo thrown at the unity of the nascent state of Pakistan was the announcement in 1948 in Dhaka by Muhammad Ali Jinnah, the founder of Pakistan, making Urdu - the language of the North Indian elite - as the state language of Pakistan. Urdu was chosen as Pakistan's state language for its supposed Islamic character (Novak, 1993: 15). The Bengalis who were the majority of Pakistan viewed this as a symbol of West Pakistan's disregard for Bengali culture and identity. Partly for this reason, though they had freely decided to join the new nation of Pakistan, which they had helped found when India was partitioned, the Bengalis soon became disenchanted and discovered the hard way that they had thrown off one colonial ruler for another (Novak, 1993: 15; Nafziger, 1976). Until 1971, Bangladesh was under a repressive system of governance imposed by the military-bureaucratic oligarchy of Pakistan (Haque, 2002: 413). 
Political and economic deprivation of the Bengalis led to the launching of political movement for autonomy in 1965 led by Sheikh Mujibur Rahman of the Awami League (AL). After a period of political struggle, the Pakistan military junta organised elections for the National Assembly in December, 1970. For the first time in Pakistan's history, general elections were held on the basis of the principle of one-man-one-vote. In that election, the AL won 167 out of 169 seats in the East and became the majority party in Pakistan's National Assembly. This election result was a surprise to the military-civil bureaucratic elite of Pakistan and in spite of Sheikh Mujibur Rahman's repeated public pledge that no harm to sovereignty or the Islamic character of Pakistan would be made, the word was spread that "the unity of Pakistan was in danger" (Mascarenhas, 1971: 61). Instead of handing over power to the AL, Pakistan's President Yahya Khan postponed the session of Pakistan's National Assembly. On the night of March 25, 1971, Pakistani troops based in East Pakistan attacked Bengalis with tanks and other modern weapons. Dubbed "Operation Searchlight", the main aim of this military crackdown was to destroy the leadership of the AL, killings and terrorising of Bengali civilians. (Sission and Rose, 1990: 157-158).

Following the Pakistan military attack, Bangladesh (former East Pakistan) declared its independence on 26 March, 1971. After a war of liberation lasting nine months, the Pakistan military surrendered to a joint military command of the Indian military and the Mukti Bahini (Freedom Fighters) on 16 December, 1971. Bangladesh paid a heavy price for its independence. In addition to the destruction of physical structures like roads, bridges, and railway tracks, nearly one to three million people had been killed and 200,000 women were raped causing 25,000 pregnancies (Akmam, 2002: 549). In addition, around one million fled the country and took shelter in the adjoining Indian states of Assam, Tripura and West Bengal.

Although independence was achieved in 1971, the people of Bangladesh are yet to achieve a society free from economic and political exploitation, violence and injustice. Political violence has be devilled the country ever since 1971. The first major case of political violence was the 1975 assassination of the founding father of the country Sheikh Mujibur Rahman and his wife, three sons, two daughters-in-law and other members of his family (the only survivors were his daughters Sheikh Hasina Wajed and Sheikh Rehana who were abroad at that time) in a military coup. During a series of coups and counter-coups in November, 1975 , a number of the country's key military and political leaders were killed. The most prominent political leaders of them were the four $A L$ leaders (Tajuddin Ahmed, Syed Nazrul Islam, Mansur Ali, and Quamruzzaman) who were brutally killed inside Dhaka Central jail. Lt. General Ziaur Rahman, who had emerged as the president of the country, himself, was killed in an abortive military coup on 30 May, 1981. Lt. General H. M. Ersahd seized power in a bloodless coup on March 23, 1982 and ruled the country until his overthrow by a popular uprising in 1990. There have been numerous reports of unrest among the country's armed forces. A major incident involving the security forces took place on February 25, 2009, when soldiers of the Bangladesh Rifles (BDR) - the country's border security forces - went on a rampage and killed more than 53 army officers including some of their family members in Dhaka. In addition, throughout the 1990s and 2000s, a number of political leaders were killed. On 21 August 2005, a bomb blast at a rally organised in Dhaka by the AL killed one of its prominent leaders Ivy Rahman, and injured Sheikh Hasina Wajed. Hasina suffered damage to her hearing as a result of this bomb attack. S.A.M.S. Kibria, a former finance minister and a respected international civil servant who worked for the UN system, was also killed in an attack in Sylhet, northern Bangladesh. In an outrageous incident, Anawarullah Chowdhury, the U.K. High Commissioner to Bangladesh was slightly injured while visiting Sylhet. Following the abortive military coup against Lt. General Ziaur Rahman, army officers were tried in military courts and hanged. The country had to wait until an ALled government, which came to power in 1996 to begin the process for the trial of the self-confessed killers of Sheikh Mujibur Rahman and his family members. It raises question about the efficiency of the judicial system of the country, which was formally separated from the executive only in 2008.

In August 2005, two Islamic religious extremist groups -Jamaat-ul-Mujahideen Bangladesh (JMB) and Jagrata Muslim Janata (JMJB) - carried out a countrywide spate of bombings in which more than 30 people were killed and 150 people were injured. In particular, the JMB demonstrated its organisational capacity when it carried out the simultaneous explosion of nearly five hundred small bombs across the country. It is also suspected to have carried out suicide bombings in Gazipur, Netrokona, and the port city of Chittagong in 2005. The JMB wants the introduction of strict sharia law in Bangladesh, and has been targeting individuals 
and organisations it accuses of advancing a secular anti-Islamic agenda (Hogg, 2006: 12). It targeted members of the judiciary, civil society, intellectuals and university teachers. JMJB created terror in the southwestern and north-eastern parts of Bangladesh creating terror in the rural areas of north-eastern and north-western parts of the country. JMB leader Shaikh Ataur Rahman and JMMB leader Siddiqul Islam were arrested and put on trial in 2006. Both were sentenced to death and carried out in 2008. There has always been a Muslim element in Bangladeshi consciousness. But the vast majority of the Bangladeshi Muslims reject extreme religious beliefs.

Although programmes such as micro-finance have substantially empowered Bangladeshi women, other social indicators concerning them are not very encouraging. For example, Bangladesh still remains as one of the few countries where female life expectancy at birth is lower than males and more than $14 \%$ of pregnant women's deaths are associated with injury and violence (Khan, 2009). In 2008, 14,284 'cruelty against women' cases were registered by police (Bangladesh Police, 2009). Ironically, corruption in the law enforcing agencies is a critical obstacle to eliminate crime and violence against women. Acid attacks against women in Bangladesh have been increasing since the early 1980s. Acid attacks involve the splashing of acid (sulphuric acid or car battery) on the face of and/or body of victims. At present NGOs and government reports put total cases at about 300 annually (Chowdhury, 2005: 163).

Certainly in a country like Bangladesh poverty works as a push factor for driving children from their families. But other factors are also responsible for this phenomenon. For example, In a study, Conticini and Hulme (2007) find that in Bangladesh social factors lie behind most street migration of children, and in particular, violence towards and abuse of children within the household and local community are responsible for pushing children out to the street. Therefore, economic growth and reductions in income poverty will be helpful but they will not be sufficient to reduce street migration by children.

Violence between cadres of various political parties is part and parcel of Bangladesh politics. However, due to the declaration of a state of emergency by a militarybacked government on 11 January, 2007, in a dramatic contrast to previous years, there was a significant reduction in deaths and injuries resulting from the political conflict among the major parties. According to news reports, there were 38 incidents of such conflict resulting in the killing of seven persons and the injury of 1,153 persons (Hossain and Siddiqi, 2008: 32). Such a reduction in the number of conflicts was due to declaration of the state of emergency on $11^{\text {th }}$ January, 2007 , and the declaration of a ban on all political activities in the country. The constitutional guarantee of the right to life that is the right not to be deprived of life save in accordance with the law, cannot be suspended or derogated from under any circumstances. Yet state security forces reportedly continued to be responsible for extra-judicial killings in the form of "cross-fire deaths", and for custodial killings, and also to be responsible for the loss of lives of among others, women and workers through failure to enforce existing laws, and for loss of livelihood of slum dwellers (Hossain and Siddqi, 2008: 28).

\section{MEMBERS OF CIVIL SOCIETY AND DEVELOPMENT OF A SOCIETY}

Adjibolosoo (2006), Kamrava (2000), and Kapai (2012), have emphasised the positive contributions that the citizens of a country can make towards developing their respective societies. They have pointed out that in their development role common citizens are in a better position to play positive roles because they can undertake a fine grained analysis of community social fabric and processes together with the associated economic, and political factors. In this section, the contributions of two ordinary individuals -Rokeya Sakhawat Hossain and Khondker Azizur Rahman Salim - would be discussed in the development process of Bangladesh. The discussion aims to show that although ordinary, by they accomplished extraordinary acts.

\subsection{Begum Rokeya Sakhawat Hossain}

A courageous feminist writer and an activist, Begum Rokeya Sakhawat Hossain devoted her life to educating women, one of the most effective ways to develop a society. Modern peace-researchers like Johan Galtung, Richard Eckhard repeatedly have emphasised educating the people to achieve the goals of developing a society. Rokeya's legacy still continues in Bangladesh where her life is an inspiration for women struggling for their rights.

Rokeya was born into a Bengali Muslim conservative upper-class family in the small village of Pairaband in the district of Rangpur, northern part of present day Bangladesh. Her exact date of birth is not known with certainty but according to a nephew of 
Rokeya, she was born on December 9, 1880. Rokeya's mother was Rahatunnessa Sabera Chowdhurani, who married widower Zahiruddin Mohammad Abu Ali Saber, a well-educated and influential landowner. Not much is known of Rokeya's mother. However, while dedicating Avarodbhasini (The Secluded Ones) to her mother, Rokeya mentions her mother living in strict purdah (seclusion). Rokeya had two brothers - AbulAsad Ibrahim Saber and Khalilur Rahman Abu JaigamSaber - and two sisters - Karimunessa and Humaira.

Following the tradition then prevalent among the upper-class Muslim families in Bengal, the education of Rokeya and her brothers differed. Her brothers received their early education at home and then sent to St. Xavier's, a prestigious college in Calcutta. But Rokeya and her two sisters received traditional education at home. They learned Arabic, so that they could read Qur'an. The sisters also learned Urdu but were not taught Bengali and English, presumably because these languages were also spoken by nonMuslims. Rokeya's eldest brother, Ibrahim Saber, however, taught her Bengali and English at home. She learned these languages secretly when everyone else in the house were asleep.

At the age of eighteen (some put it at sixteen) Rokeya was married off to Syed Sakhawat Hossain, a widower in his late thirties. He was a district magistrate in Bihar under the Bengal Presidency. An open-minded person, Syed Sakhawat was educated both locally and in London. Following the marriage, they settled in Bhagalpur, Bihar. Rokeya's husband, convinced that the education of women was the best way to cure society's ills set aside Rupees 10,000 for a school for Muslim women. After eleven years of marriage, Syed Sakhawat died in 1909, and Rokeya immediately started a school "Sakhawat Memorial Girls' School" in Bhagalpur, Bihar. Unfortunately for her, a family dispute over property forced her to close this school. Undaunted she moved back to Calcutta where in 1911, she re-started her school. The number of students increased from a mere eight in 1911 to eighty-four in 1915. In 1917, the school was visited by Lady Chelmsford, wife of the Governor-General of India. Following her visit, Rokeya's school began to receive the patronage of prominent people of the society. By 1930, the school had evolved into a high school (ten grades) where Bengali and English were taught as regular subjects.

Gradually Rokeya got involved in civil affairs. In 1916, she founded the Anjuman-e-Khawatin-e-Islam,
Bangla (Bengali Muslim Women's Association). In 1926, at her invitation the Bengal Women's Education Conference was held in Calcutta. She was active in debates and conferences concerning the advancement of women until her death on 9 December, 1932, shortly after presiding over a session during the Indian Women's Conference in Aligarh. She was grieved by many male and female Hindu and Muslim activists, including educators as well as liberal leaders of India.

Rokeya's essays, mostly written in Bengali, were designed to gain support for the cause of women. These were published during the twenty years she spent in Calcutta after her husband's death. Her essays in two volumes of Motichur (Pearl Dust) have been compared to the work of eighteenth-century English feminist Mary Wollstonecraft in Vindication of the Rights of Woman.It is unlikely that Rokeya knew about Mary Wollstonecraft but Rokeya's writings and active life dedicated to the cause of women is a clear indication that feminism can have indigenous roots and does not need to depend on foreign influence. She had combined writing and activism, which is unfortunately not commonly found among the members of the contemporary academic community. Though Rokeya fought for women's rights, she did not reject veiling completely. She advocated modesty and argued that veiling should not hinder formal education of women, something many in contemporary Pakistan, Afghanistan, and elsewhere in the Muslim world should take lessons from.

It was through Sultana's Dream that Rokeya expressed her inner desires for a country without fear and oppression for women. In this novel she describes a land where women have taken over the reins of the country. The men stay inside the mardana, working in the kitchen and looking after the children. In this world of Rokeya, women have mastered sun-heat (solar power) and water from the environment and are in harmony with nature. Only if Rokeya's world was the reality, the world would not be facing such an environmental crisis.

In Bangladesh, Rokeya Sakhawat Hossain's legacy is that of a Muslim woman who was born and raised in purdah. Yet, through strong determination, she was able to rise above the limitations that her society placed upon her. With the help of her brother and husband, she was able to write not only in Bengali as well as in English but took significant steps to educate women in her country. She remains a beacon to all peace-loving people of the country. 


\subsection{Khondker Azizur Rahman Salim}

Khondker Azizur Rahman Salim, unlike Rokeya Sakhawat Hossain, is a businessman. But in his own way, he shares Rokeya's intense passion for doing positive deeds for the good of the society. Born in Dhaka on $21^{\text {st }}$ February, 1952, into a very well-known and respected Bengali zaminadar (landlord) family hailing from Deuli, Patuakhali, located in the southern part of Bangladesh, Salim can be described as a selfmade person. When he was only in his twenties, he had to take up the responsibility of his family, when on $2^{\text {nd }}$ April 1971, his father was shot and killed by Pakistan military personnel in Jinjira, an area on the other side of the river Buriganga, plying next to Dhaka city. Salim, his younger brother Khondker SultanulAlam, only sister Khondker Salina Akhtar, mother Roushan Ara Begum, and father Khondker Abdul Mannan, were brought out by Pakistan military personnel from a house where the family had taken shelter to escape the widespread killing of civilians by the Pakistan military in Jinjira. Salim's father stood in front of the soldiers when they started shooting at the family. Mannan was mortally wounded and literally bled to death as he could not be given any medical attention. Salim's mother, distraught watching her husband shot dead, and the youngest son shot and wounded during the shooting, suffered from mental depression for a very long time.

With the death of his father, the responsibility of looking after the family fell on Salim. While studying for his Bachelor's in Science degree, he took over his late father's business interests and gradually took control of Niramoy(Cure) Pharmaceuticals, a small pharmaceutical factory owned by his late father. Like other small pharmaceutical factories in the country, Niramoymade, among others, distilled water for injection, antacid, and vitamin tablets. Later, as the time passed by Salim expanded the factory's range of medicines including anti-biotic. By late 1970s and early 1980s, Niramoy was well established. Salim was passionate about laying down regulations so that the pharmaceutical industry in Bangladesh could flourish and produce quality products. A firm believer in the free-market economy, he was convinced that foreign pharmaceutical factories in Bangladesh were producing unnecessary products and over-charging the people. Although most Bangladeshis had no access to lifesaving drugs, Salim believed a large number of wasteful and undesirable medicinal products were manufactured and marketed under commercial pressure. Therefore, he was in favour of a policy simplifying the range of drugs available in the country and improving their distribution at reasonable price.

Salim got his chance in 1982 when a group of local manufacturers of pharmaceutical products under the leadership of $\mathrm{Dr}$. Zafrullah Chowdhury, founder of Ganoshastro Kendro (GK) got together to push for the adoption of a new drug policy. Dr. Zafrullah was later appointed by the government of Bangladesh in April, 1982 as a member of the eight-member Expert Committee, tasked with the formulation of a New Drug Policy (NDP). Salim was motivated by the World Health Organisation's (WHO) essential drugs concept such as access to essential medicines, quality of all medicines and rational use of drugs. On 2 June, 1982, the military government of Lt. General H. M. Ershad promulgated the New Drug Policy. Although Dr. Zafrullah has been dubbed as the "father" of the 1982 New Drug Policy, many people like Salim worked tirelessly day and night mulling strategies and trying to convince the military government of the need for such a policy by lobbying government officials. Salim used his home as a meeting place of the group, where they would meet and discuss issues related to the New Drug Policy. It was interesting to watch this group of professionals arguing their respective points of view. There were of course divisions, disagreements among them on strategy but there was no question about their commitment to bring about a change in the country's drug policy.

This small group of dedicated people found their greatest ally in the person of Lt. General H. M. Ershad, the new military ruler of the country who had taken over power on 23 March, 1982. He later proved to be a crafty political leader and presided over a political system which was marred by its authoritarian nature and corruption. But there was no question of his commitment to change the country's drug policy. At that time, there was speculation that the military dictator had negative views of the medical profession because some doctors refused to visit his mother who was sick, and proper drugs could not be administered to her. Soon after he had taken over power, Ershad fixed doctors' fees and made it compulsory for all government specialists' jobs transferable. Though these moves were potentially beneficial to common people, this policy was reversed in the face of stiff resistance from the medical professionals.

As mentioned earlier, in April, 1982, the military government appointed an eight-member Expert Committee to review all the registered/licensed 
pharmaceutical products in the country and formulate a NDP. This committee, which included Dr. Zafrullah, consisted of academics, regulatory experts, and health activists. But this committee did not include any representatives from the industry and bureaucracy. Therefore, the executive committee members - wellconnected to the multinationals - of the Bangladesh Medical Association (BMA) were also excluded.

The main aim of this committee was to protect the consumer and at the same time help the local pharmaceutical companies. The committee worked intensively for about two weeks and submitted its report to the Government on 11 May, 1982. The committee reviewed 4140 products marketed by 176 companies, including 8 multinationals which controlled over $80 \%$ of the drug market in Bangladesh (Anonymous, 1982: 1405). It must be pointed out here that at the time of the evaluation of the drug policy, foreign pharmaceutical companies based in Bangladesh had done very well. With nearly unlimited credit from the banks, they brought little capital into the country (Anonymous, 1982: 1406). Table 1 spells out the huge volume of business enjoyed by the multinationals with very small initial investment.

The Expert Committee had developed a list of 16 criteria by which to evaluate all registered/licensed pharmaceutical products imported or manufactured in Bangladesh. Eleven of these criteria were based on efficacy considerations, one encouraged multinationals to focus on items not easily produced in the country by denying them production of antacids and vitamins, while the other criteria were solely based on protection of the domestic drug manufacturers. ${ }^{1}$

On 12 June, 1982, the government accepted the committee's recommendations and announced a New Drug Policy (NDP). A Martial Law Ordinance was promulgated in this regards. The objectives of the NDP were to

1. provide support for ensuring quality and availability of drugs;

2. reduce the price of drugs;

3. support for ensuring quality and availability of drugs;

4. promote local production of finished drugs;
5. ensure coordination among government branches;

6. develop a drug monitoring and information system;

7. promote scientific development and application of Unani, Ayuverdic and Homeopathic medicines;

8. improve the standard of hospital and retail pharmacies; and

9. $\quad$ ensure good manufacturing practices. $^{2}$

The NDP classified drugs in Bangladesh into three categories. Under the first category 265 locally manufactured and 40 imported drugs were declared hazardous. These were banned and ordered to be withdrawn from the market immediately. Under the second category, 134 drugs were required to change some of their formulations. Under the third category over 500 drugs were found not to be in conformity with the committee's guidelines. These were considered of no value for health and were identified as a drain on consumers' resources. However, these drugs were to be allowed in the market for six months. Foreign companies were not to be allowed to produce the same drugs that local manufacturers produce, and multinationals that did not have manufacturing plants in Bangladesh were not allowed to sell their products in country. The NDP also recommended that a list of 150 essential drugs be drawn up. It further called for the creation of a list of 100 specialised drugs for use at tertiary level. The use of generic names for manufacture, prescription and sales was introduced. Changes were made in patenting laws and controls were put on advertising, labelling, prescription, pricing, technology transfer, licensing arrangements, and pharmacies.

Salim was ecstatic about the NDP although it was very clear to him that all pharmaceutical manufacturers in the country would be adversely affected directly; with the locally-owned firms hit the hardest. He along with some members of the local Bangladeshi pharmaceutical producers whole-heartedly welcomed the NDP. They strongly believed that it was now possible for the local companies to develop properly. They were right to be optimistic about the future of

\footnotetext{
${ }^{2}$ From written notes kept by Khondker Azizur Rahman Salim. 
Table 1: Volume of Business Enjoyed by Multinational Pharmaceutical Companies In Bangladesh

\begin{tabular}{|c|c|c|}
\hline Company & Initial Investment & Business Volume 1981 \\
(million taka) & (million taka) & 200 \\
\hline \hline Pfizer & 11.4 & 140 \\
\hline Fisons & 0.54 & 120 \\
\hline May and Baker & 4.5 & 115 \\
\hline Hoechst & 0.65 & 110 \\
\hline Glaxo & 4.15 & 105 \\
\hline Squibb & 1.43 & 50 \\
\hline ICI & 2.1 & 50 \\
\hline Organon & 0.88 & 5 \\
\hline
\end{tabular}

Source: Consumer Voice, March 1982 (Dhaka: Consumer Association of Bangladesh).

locally-produced drug manufacturing in the country. Following the 1982 NDP, local pharmaceutical companies improved the range and quality of their products. Local companies increased their share from $25 \%$ to $70 \%$ on total annual production between 1981 and 2000. At present $95 \%$ of the total demand of medical products is met by local production. In 2002, the total size of the pharmaceutical market was estimated at US\$520 million. One of the major positive impacts of the 1982 NDP was the rapid development of local manufacturing capability. Almost all types of possible dosage form including tablets, capsules, oral and external liquids, ointments, creams, injections and aerosol inhales are now produced in the country. Pharmaceutical products are now exported to Vietnam, Singapore, Malaysia, Bhutan, Nepal, Sri Lanka, Pakistan, Oman, Yemen, Thailand and some countries in Central Asia and Africa.

The NDP was criticised by foreign drug manufacturers. For example, the US-based Pharmaceutical Manufacturers Association (PMA) published a report which claimed that the drug policy had fallen short of its objectives, and had "not made even the slightest dent in the massive problem of improving the availability of important drugs to the 70$85 \%$ of the population that lacks access to them" (Anonymous, 1985: 1351). The PMA report further claimed that 100 out of 160 manufacturers in Bangladesh have no quality control operations "worthy of mention" and that "the use of such products could become a major health problem" (Anonymous, 1985: 1352). Dr. Zafrullah Chowdhury described the PMA report as "wrong". He pointed out that an expert team from the Swedish and Danish Governments visited the country and found that the quality of Bangladeshi drugs had improved (Anonymous, 1985: 1352).
The multinational companies had a three pronged strategy to oppose the 1982 NDP. First of all, the US ambassador to Bangladesh intervened directly (Chowdhury, 1995). On 1 June, 1982, when the media broke the news about the Council of Minister's approval of the NDP, the same morning the American ambassador called on General Ershad without an appointment. General Ershad was told that the NDP was unacceptable to the US. Therefore, it should not be implemented. Second, the Western governments led by the US strongly lobbied the Bangladesh Medical Association (BMA). Instead of launching an attack on the scientific demerits of the policy they focused instead on generating fear that the regulation of drugs would damage the foreign investment climate of the country (Chowdhury, 1995). The third strategy was directed at discrediting and undermining the supporters of the NDP. For example, the BMA revoked the membership of prominent supporters of the NDP including the minister of Health and Dr. Zafrullah Chowdhury. Following the removal of the sympathetic Director of the Drug Administration, supporters of the NDP like Salim were threatened, harassed and hauled up for violation of drug rules. Salim's manufacturing license was cancelled on trumped up charges. But no amount of intimidation or threat could stop the implementation of the NDP.

One of the main objectives of the NDP was to boost the capacity of local producers of drugs, and as pointed out above, it has been fairly successful. But one of the negative impacts of the NDP was the elimination of many small and medium-size local pharmaceutical manufacturers. Lacking sufficient capital, and technical expertise, they were eventually squeezed out of business by big local companies. One such victim was Salim himself. He anticipated such a scenario, and in a 
few years, he had to fold up Niramoy Pharmaceuticals. Salim's contribution to the 1982 NDP was his enthusiasm and conviction. He was convinced that such a policy would benefit the local drug manufacturers, and he proved correct. He did not flinch from his support of the 1982 NDP even when he knew that his personal business interests could be adversely affected by the NDP. So he made the ultimate sacrifice and folded up his company because he thought doing pharmaceutical business in Bangladesh has become "dangerous".

\section{CONCLUSION}

It is often argued that peace in a society can be brought about by the visions and deeds of great leaders like Mahatma Gandhi, Martin Luther King Jr., Nelson Mandela and many others. While it is easy to assess their contributions, it is difficult to assess the roles of people that are needed to turn the great leaders' visions into the reality. This article analysed the contributions of two ordinary people towards the cause of improving the lives of common people in Bangladesh. Begum Sakhawat Hossain was an ordinary housewife at a time when women were not encouraged to learn English. Yet, through perseverance and determination, she not only educated herself but had taken practical steps to educate Muslim women. In many ways, she was also a path-breaker for feminism. In her well-known Sultana's Dreams, Begum Rokeya thought of a land where the women are in charge while the men live inside. This would be the dream of every feminist of the contemporary period.

Khondker Azizur Rahman Salim worked hard behind the scene for the 1982 National Drug Policy. Salim -a producer of pharmaceutical products in 1982-was totally convinced that such a policy would be a boost for the local pharmaceutical industry. He also knew that small and medium sized pharmaceutical producers like him would be adversely affected by the 1982 NDP. On both account, he proved to be absolutely right. The local pharmaceutical industry in Bangladesh is now worth more than US $\$ 500$ million exporting medicines to various European, Asian, central Asian and African countries. Once the 1982 NDP was implemented, Salim's pharmaceutical factory could not compete with the local large companies. Therefore, he had to shut it down and now he is no longer in pharmaceutical business.

\section{REFERENCES}

Adjibolosoo, Senyo, B-S, K. 2006. Developing civil society: Social order and the humanfactor. Aldershot: Ashgate.

Ahmed and Erfan, 2008. 'Microcredit, men and masculinity,' NWSA Journal, vol. 20, no. 2, Summer: 122-155.

Akmam, W., 2002. 'Atrocities against humanity during the Liberation War in Bangladesh: A case of genocide,' Journal of Genocide Research, vol. 4, no. 4, December: 543-559. http://dx.doi.org/10.1080/146235022000000463

Anonymous. 1982. 'Bangladesh: A national drug policy'. The Lancet, 19 June, 1982: 1405-1406.

Anonymous. 1985. 'Bangladesh: Criticism of new drug policy'. The Lancet, 14 December, 1985: 1351-1352.

Bangladesh Police. 2009, 'Crime statistics,' available at http://www. police.gov.bd/index5.php accessed on 6 April, 2009.

Barthwal-Datta, Monika. 2009. 'Securitizingthreats without the State: A case study of misgovernance as asecurity threat in Bangladesh.' Review of International Studies, vol. 35, no. 2, April, pp. 277-300. http://dx.doi.org/10.1017/S0260210509008523

Brooks, E.C., 2007, Unveiling the garment industry: Transnational organizing and women's work, University of Minnesota Press, Minneapolis.

Chowdhury, E. H., 2005, 'Contesting narratives of the campaign against acid violence in Bangladesh,' Meredians: Feminism, race, Transnationalism, vol. 6, no. 1, pp. 163-192.

Chowdhury, Z., 1995, Thepolitics of essential Drugs: The makings of a successful health strategy: Lessons from Bangladesh. London: Zed Books with Dag Hammarskjöld Foundation.

Conticini, A., and Hulme, D., 2007, 'Escaping violence, seeking freedom: Why children in Bangladesh migrate to the street, Development and Change, vol. 38, no. 2, pp. 201-227. http://dx.doi.org/10.1111/j.1467-7660.2007.00409.x

Ghani, Ashraf and Lockhart, Clare, 2008, Fixing failed States. Oxford: Oxford University Press.

Hogg, C. H., 2006, 'Unconvincing crackdown,' Theworld today, vol. 62, no. 7 (July, 2006), pp. 12-13.

Hossain, I., 1998, 'An experiment in sustainable human development: The Grameen Bank of Bangladesh', Journal of third world studies, vol. 15, no. 1, Spring, pp. 39-55.

Hossain, S., and Siddiqi, D.M., 2008, Human rights in Bangladesh 2007, Ain o Salish Kendra, Dhaka.

Islam, M. S., 'A Review on the Policy and Practices of Therapeutic Drug Uses in Bangladesh', Calicut Medical Journal, Vol. 4, No. 4: 1-6.

Kapai, Puja. September, 2012. "Developing capacities for inclusive citizenship in multicultural societies: The role of deliberative theory and citizenship education." Public Organization Review, vol. 12 no. 3, pp. 277-298. http://dx.doi.org/10.1007/s11115-012-0182-y

Kamaran, Mehran. 2000. Politics and society in the developing world. New York: Routledge.

Khan, S., 2009, 'Violence against women: Bangladesh Context,' available at hurights.or.jp/asia-pacific/040/02.htm accessed on 6 April 2009.

Mascarenhas, A., 1971, The Rape of Bangladesh, Vikas, New Delhi.

Nafziger, E.W., and Richter, W.L., 1976, 'Biafra and Bangladesh: The political economy of secessionist conflict,' Journal of Peace Research, vol. 13, no. 2, pp. http://dx.doi.org/10.1177/002234337601300202

Novak, J., 1993, Bangladesh: Reflections on the water. Indiana University Press, Bloomington, Indiana.

Quayum, Mohammad A. 2013. The essential Rokeya: Selected works of Rokeya Sakhawat Hossain (1880-1932). Leiden: Brill.

http://dx.doi.org/10.1163/9789004255876 
Rahman, A.T.R., 2006. Bangladesh in the Mirror: An Outsider Perspective on a Struggling Democracy, The University Press Limited, Dhaka.

Rahman, Sohel, 2006, 'Development, democracy and the NGO sector: Theory and evidence from Bangladesh', Journal of development societies, vol. 22, no. 4, December, pp. 451473.

http://dx.doi.org/10.1177/0169796X06072650
Sission, R. and Rose L. E., 1990, War and secession: Pakistan, India, and the creation of Bangladesh, University of California Press, Berkeley.

Zoellick, Robert 2008-2009, 'Fragile states: Securing development', Survival, vol. 50, no. 6, December-January, pp. 67-84. http://dx.doi.org/10.1080/00396330802601859

Received on 07-10-2015

Accepted on 05-11-2015

Published on 31-12-2015

(C) 2015 Ishtiaq Hossain; Licensee Lifescience Global.

This is an open access article licensed under the terms of the Creative Commons Attribution Non-Commercial License (http://creativecommons.org/licenses/by-nc/3.0/) which permits unrestricted, non-commercial use, distribution and reproduction in any medium, provided the work is properly cited. 